\title{
Human alveolar epithelial cells induce nitric oxide synthase-2 expression in alveolar macrophages
}

\author{
D.V. Pechkovsky*, G. Zissel*, C. Stamme ${ }^{\#}$, T. Goldmann*, H. Ari Jaffe ${ }^{\top}$, M. Einhaus ${ }^{+}$, \\ C. Taube ${ }^{+}$, H. Magnussen ${ }^{+}$, M. Schlaak*, J. Müller-Quernheim*
}

Human alveolar epithelial cells induce nitric oxide synthase-2 expression in alveolar macrophages. D.V. Pechkovsky, G. Zissel, C. Stamme, T. Goldmann, H. Ari Jaffe, M. Einhaus, C. Taube, H. Magnussen, M. Schlaak, J.Müller-Quernheim. (CERS Journals Ltd 2002.

ABSTRACT: It was hypothesized that cell-to-cell interaction between human alveolar macrophages (AM) and alveolar epithelium, might be an important factor leading to nitric oxide synthase-2 (NOS2) messenger ribonucleic acid (mRNA) and protein expression by constituent cells of the alveolar wall and/or AM.

NOS2 mRNA and the protein expression patterns of human AM and alveolar epithelial cells type II (AEC-II) isolated from normal parts of lung resections of patients with pulmonary malignancies were determined. In addition, NOS2 mRNA expression in human AM co-cultured with autologous AEC-II in the presence of pro-inflammatory cytokines interleukin (IL)-1 $\beta$, tumour necrosis factor (TNF)- $\alpha$, interferon (IFN)- $\gamma$ or lipopolysaccharide (LPS) was investigated. The effect of human surfactant protein-A (SP-A) on IFN- $\gamma$-mediated NOS2 mRNA expression in human AM was also studied.

Neither NOS2 mRNA nor protein could be detected in freshly isolated, unstimulated or cytokine-stimulated AEC-II. In contrast, freshly isolated AM from bronchoalveolar lavage or lung tissue samples expressed immunoreactivity for NOS2 protein, but no NOS2 mRNA could be detected by reverse transcriptase polymerase chain reaction. All stimuli tested failed to induce NOS2 mRNA expression in human AM in vitro. Only AM-AEC-II co-culture in the presence of IFN- $\gamma$ led to NOS2 mRNA and protein expression. In situ hybridization of NOS2 mRNA on lung tissue explants and immunohistochemical staining of cytospin preparations of AM-AEC-II co-cultures demonstrated that NOS2 is expressed in AM but not in AEC-II. This co-culture effect could not be reproduced by substitution of AEC-II with SP-A.

These data give evidence of a regulatory network controlling human nitric oxide synthase-2 expression in the lower respiratory tract.

Eur Respir J 2002; 19: 672-683.
* Medical Hospital, Research Centre Borstel, Borstel and " Dept of Anaesthesiology, University Hospital Lübeck, Lübeck, Germany. "Dept of Medicine, University of Illinois, Chicago, USA 'Krankenhaus Grosshansdorf, Grosshansdorf, Germany.

Correspondence: G. Zissel, Dept of Pneumology, University Hospital Freiburg, Kilianstrasse 5, 79106 Freiburg, Germany.

Fax: 497612703704

E-mail: Zissel@medizin.ukl.uni. freiburg.de

Keywords: Alveolar epithelial cells type II, alveolar macrophages, cytokines, nitric oxide synthase-2, reverse transcriptase polymerase chain reaction, surfactant protein $\mathrm{A}$

Received: May 152001

Accepted after revision November 8 2001

This study was supported in part by a grant from the Deutsche Forschungs gemeinschaft (No. Mu 6623/5-5). D.V. Pechkovsky is a recipient of a research fellowship from the European Respiratory Society and the Borstel Foundation.
Nitric oxide (NO) is a gas that can be detected in exhaled air and its increase is observed in several pulmonary disorders including tuberculosis, sarcoidosis, idiopathic pulmonary fibrosis (IPF), primary lung cancer, and adult respiratory distress syndrome (ARDS) [1-5]. Exhaled NO has been shown to be an indirect marker of airway inflammation; alveolar macrophages (AM) and airway epithelial cells are assumed to be the main source of the elevated levels of NO [1-5].

Prolonged and enhanced NO production is thought to occur predominantly through the action of nitric oxide synthase type-2 (NOS2). Although several investigators have shown that human AM can be induced to express NOS2 in vivo, their ability to express NOS2 and to generate NO in response to an in vitro stimulation is still under debate $[6,7]$. One reason for this controversy may arise from complex inflammatory processes within the alveoli responsible for NOS2 messenger ribonucleic acid (mRNA) expression, enzyme production, and NO generation by human AM. Despite numerous potential mechanisms, which can modulate NOS2 expression in the injured alveolar compartment, one common pathway is the formation of cytokine profiles within alveoli by constituent and recruited cells, including AM and T-lymphocytes. More specifically, the accumulation of NOS2 mRNA and/or protein has been documented in AM or alveolar epithelium of patients suffering from pulmonary tuberculosis, sarcoidosis or IPF. This NOS2 expression is probably induced by pro-inflammatory cytokines such as tumour necrosis factor (TNF)- $\alpha$, interleukin (IL) $-1 \beta$, and interferon (IFN)- $\gamma[2,8,9]$. Either by direct production of NO or by expression of excessive amounts of bioactive substances, which in turn mediate NO production by both $\mathrm{AM}$ and alveolar epithelium, these cells may play an important role in lung injury and inflammation. Nevertheless, the cooperative contribution of alveolar epithelial cells type II (AEC-II) and AM to these processes is unclear. 
The capabilities of human AM to control the NOS2 expression and NO production of the murine lung epithelial cell line LA- 4 by IL- $1 \beta$ and TNF- $\alpha$ has been demonstrated by RoBbins et al. [10]. It has also been shown that surfactant protein A (SP-A), which is abundantly produced by AEC-II, induces NOS2 expression and NO production by rat AM [11]. In contrast, more recently, the authors reported that human SP-A itself did not affect production of NO or NOS2 protein expression in rat AM, but it significantly enhanced NOS 2 protein production in IFN- $\gamma$ or lipopolysaccharide (LPS)/IFN- $\gamma$ stimulated cells [12].

The authors hypothesized that cell-to-cell interaction between human AM and alveolar epithelium during inflammation might play a pivotal role in their NOS2 mRNA accumulation and protein expression. To test this hypothesis, human AM and AEC-II isolated from normal parts of lung resections of patients with pulmonary malignancies were examined, for their capabilities to express NOS2 mRNA and protein in primary culture. In addition the NOS2 expression patterns in human AM co-cultured with autologous AEC-II, both in the absence or presence of pro-inflammatory cytokines (IL-1 $\beta, \mathrm{TNF}-\alpha$, IFN- $\gamma$ ) or LPS were determined. The effect of human SP-A on IFN- $\gamma$-mediated NOS2 mRNA expression in human AM was also studied.

It was found that NOS2 mRNA and protein are absent in freshly isolated, unstimulated or cytokinestimulated AEC-II. In contrast, freshly isolated human AM from either bronchoalveolar lavage (BAL) or lung tissue samples expressed immunoreactivity for NOS2 protein, but no NOS2 mRNA could be detected by reverse transcription polymerase chain reaction (RT-PCR). All stimuli tested failed to induce NOS2 mRNA expression in human AM in vitro. Only AM-AEC-II co-culture in the presence of IFN- $\gamma$ led to NOS 2 mRNA accumulation and protein production in AM. This co-culture effect could not be reproduced by substitution of the AEC-II with SP-A.

These data give evidence of a regulatory network controlling human NOS2 expression in the lower respiratory tract.

\section{Materials and methods}

\section{Specimens}

BAL fluid samples were obtained from subjects who underwent bronchoscopy for diagnostic reasons. Five patients with normal chest radiographs and pulmonary function tests entered the study. BAL was performed as previously described [13]. In addition, $\mathrm{AM}$ and AEC-II were isolated from 10 lung tissue samples, which were obtained from resected lung material. All subjects were smokers and had no respiratory tract infection within the last month. None were taking antibiotics or immunosuppressants at the time of investigation. Informed consent was obtained from all subjects. The study was approved by the appropriate review or medical ethics committees of the institutions involved.

\section{Primary human alveolar epithelial cells type II}

Samples were cut from the surgical specimens and used for a cell isolation procedure as described previously [14]. In brief, lung tissue was sliced and slices were washed three times at $4^{\circ} \mathrm{C}$ in phosphate buffered saline (PBS; Gibco BRL, Paisley, Scotland) followed by an incubation in sterile dispase solution at $37^{\circ} \mathrm{C}$ for $45 \mathrm{~min}$. After dispase digestion the lung tissue slices were cut into small, pipetable pieces, and thoroughly pipetted for $10 \mathrm{~min}$. Crude tissue and cell suspensions were filtered through nylon gauze with meshes of 100,50 , and $20 \mu \mathrm{m}$. The resulting single-cell suspension was placed on Ficoll separating solution and centrifuged at $800 \times g$ for $20 \mathrm{~min}$. The AEC-IIenriched cells from the interphase were incubated in $100 \mathrm{~mm}$ plastic dishes (NUNC, Wiesbaden, Germany) at $37^{\circ} \mathrm{C}$ in humidified air containing $5 \%$ carbon dioxide $\left(\mathrm{CO}_{2}\right)$ for 15,20 and $30 \mathrm{~min}$ with seeding of nonadherent cells on fresh dishes for each time interval to remove adherent cells (mostly AM and monocytes). To remove the remaining monocytes/ macrophages and lymphocytes, antibodies against CD3 (OKT3, ECACC 86022706) and CD14 (ATCC HB-246) were added and the antibody-binding cells were removed by antimouse immunoglobulin (Ig)-G coated magnetic beads and Magnetic Activated Cell Sorting (MACS) system (Miltenyi Biotec, Bergisch Gladbach, Germany) as suggested by the supplier. Identity of AEC-II was confirmed by a modified Papanicolaou staining, their alkaline phosphatase activity, and SP-A mRNA expression in RT-PCR (see later). Cell purity was assessed by immunoperoxidase staining with monoclonal antibodies directed against CD3 and CD14 (Immunotech, Marseille, France) as previously described [15]. Viability of the AEC-II after isolation was $>97 \%$ as determined by trypan blue exclusion.

\section{Alveolar macrophages}

Human AM were isolated from BAL fluid samples and from the adherent cell fraction during AEC-II purification procedures. BAL fluid was filtered through a sterile nylon gauze filter, centrifuged at $500 \times g$ for $10 \mathrm{~min}$ at $4^{\circ} \mathrm{C}$, and the cell pellet was washed with cold PBS. Cell differentials were determined by counting a minimum of 200 cells in a cytocentrifuge preparation (Cytospin II, Shandon, Pittsburgh, PA, USA) stained by Hemacolor ${ }^{\mathrm{TM}}$ (E. Merck, Darmstadt, Germany). These cell suspensions contained $>97 \%$ AM, $1-2 \%$ lymphocytes, and $<1 \%$ neutrophil granulocytes. The viability of the cells was $>95 \%$. For isolation of AM from the same lung-tissue sample as AEC-II, the adherent cells were harvested from plastic dishes with a cell scraper and vigorous pipetting after the addition of cold PBS. The cells were treated with mouse antibodies against human CD14 (ATCC HB-246) and CD14-positive (CD14+) 
cells were separated by MACS. After MACS purification, CD14+ cells were washed twice with PBS at $4{ }^{\circ} \mathrm{C}$. The cell suspension contained $>85 \% \mathrm{AM}$, as assessed by specific morphology of the human AM, and by immunoperoxidase staining with monoclonal antibodies directed against CD14 as previously described [15]. Contaminating cells were lymphocytes (5-10\% CD3+ cells) and AEC-II (5-10\% cells). Viability of the AM after isolation was $>95 \%$.

\section{A549 cell line}

A549 cells were a generous gift from T. Papadopoulos (University of Erlangen, Germany). This cell line was used as the positive control for NOS2 mRNA expression and protein production upon stimulation with pro-inflammatory cytokines and LPS. Experiments were performed with cells after seven passages, after thawing and inoculation in culture. Cells were grown on a $75-\mathrm{cm}^{2}$ tissue culture flask (NUNC) in culture medium (Roswell Park Memorial Institue (RPMI) 1640 medium (Gibco BRL) with $2 \mathrm{mM}$ L-glutamine, $10 \%$ heat inactivated foetal calf serum (FCS; Gibco BRL), 1\% penicillin/streptomycin solution (Biochrom, Berlin, Germany), 1\% sodium pyruvate solution (Biochrom) and $20 \mathrm{mM}$ HEPES (Gibco BRL)) in a humidified atmosphere containing $5 \% \mathrm{CO}_{2}$ at $37^{\circ} \mathrm{C}$ for 5 days. After this culture period, cells were removed from plastic surfaces by treatment with trypsin/ethylenediamine tetraacetic acid (EDTA) solution (Boehringer-Mannheim, Mannheim, Germany) $\left(0.05 / 0.02 \%\right.$ in PBS) for $10 \mathrm{~min}$ at $37^{\circ} \mathrm{C}$, washed twice in PBS and resuspended in culture medium.

\section{Cell cultures}

To assess the effect of stimulation on NOS2 gene expression, AEC-II and AM $\left(1 \times 10^{6}\right.$ cells $\left.\cdot \mathrm{mL}^{-1}\right)$ were treated with Salmonella minnesota LPS $\left(1 \mu \mathrm{g} \cdot \mathrm{mL}^{-1}\right.$; K. Brandenburg, Research Centre Borstel, Borstel, Germany), recombinant TNF- $\alpha$ (1-10 ng. $\mathrm{mL}^{-1}$; E. Schlick, Knoll AG, Ludwigshafen, Germany), recombinant human IFN- $\gamma \quad\left(10-100 \mathrm{U} \cdot \mathrm{mL}^{-1}\right.$; Biotrend, Köln, Germany) or recombinant human IL-1 $\beta$ (10 $100 \mathrm{U} \cdot \mathrm{mL}^{-1}$; Biotrend), and with a combination of these stimuli in collagen-R coated (Serva, Heidelberg, Germany) 24 well plates (NUNC) at $37^{\circ} \mathrm{C}$ for $24 \mathrm{~h}$. For time-course experiments, cells were incubated in the presence or absence of LPS $\left(1 \mu \mathrm{g} \cdot \mathrm{mL}^{-1}\right)$, TNF- $\alpha\left(5 \mathrm{ng} \cdot \mathrm{mL}^{-1}\right)$, IFN- $\gamma\left(50 \mathrm{U} \cdot \mathrm{mL}^{-1}\right)$, or IL- $1 \beta$ $\left(50 \mathrm{U} \cdot \mathrm{mL}^{-1}\right)$ for $4,8,16$, or $24 \mathrm{~h}$. In separate experiments, AEC-II were co-cultured with 2.5, 5,10 or $15 \%$ of autologous AM either with or without LPS, TNF- $\alpha$, IL-1 $\beta$ or IFN- $\gamma$ at the concentrations stated earlier. AM from BAL were stimulated with LPS ( 1 and $\left.10 \mu \mathrm{g} \cdot \mathrm{mL}^{-1}\right)$, IFN- $\gamma$ $\left(10-100 \mathrm{U} \cdot \mathrm{mL}^{-1}\right)$, or the combination of INF- $\gamma$ with SP-A $\left(1-100 \mu \mathrm{g} \cdot \mathrm{mL}^{-1}\right.$; J.R. Wright, Duke University, Medical Centre, Durham, NC, USA). Pulmonary SP-A was isolated from lung lavage fluid from patients with alveolar proteinosis as previously described [16] and used in preparation containing
$<0.2 \mathrm{pg}$ endotoxin $\cdot \mu \mathrm{g} \mathrm{SP}-\mathrm{A}^{-1}$. A549 were incubated with or without LPS $\left(1 \mu \mathrm{g} \cdot \mathrm{mL}^{-1}\right)$, or cytokines for $24 \mathrm{~h}$ using the same protocol as for primary AEC-II or AM. After culture, cell viability always exceeded $95 \%$ in both AEC-II and AM as determined by trypan blue exclusion. Cell-culture supernatants were removed and cells were lysed with Trizol reagent (Gibco BRL). Cell lysates were frozen and kept at $-70^{\circ} \mathrm{C}$ before ribonucleic acid (RNA) isolation. For samples of RNA from freshly isolated cells, AM from BAL fluids, AM from lung tissue samples and AEC-II were subjected to RNA isolation procedures before culture, henceforth referred to as noncultured controls.

\section{Reverse transcriptase-polymerase chain reaction}

Total RNA was extracted from cells using Trizol according to the manufacturer's protocol. Equal amounts of total RNA from each sample were primed with oligo $(\mathrm{dT})_{12-18}$ primer (Gibco BRL) and reverse-transcribed with SuperScript ${ }^{\mathrm{TM}}$ RNase $\mathrm{H}^{-}$ reverse transcriptase (Gibco BRL) for $1 \mathrm{~h}$ at $37^{\circ} \mathrm{C}$ to produce complementary deoxyribonucleic acid (cDNA). PCR amplification of the cDNA $(2.5 \mu \mathrm{L})$ was carried out using primer pairs specific for $\beta$-actin and NOS2. To demonstrate that RNA samples from AEC-II were not significantly contaminated by RNAs from other type of cells (AM or lymphocytes) CD3- and CD14specific primers were also used. Sequences of the primers for analysis of mRNA's: NOS2 (forward): TCCGAGGCAAACAGCACA TTC; NOS2 (reverse): GGGTTGGGGGTGTGGTGATGT; $\beta$-actin (forward): AGC GGG AAA TCG TGC GTG; $\beta$-actin (reverse): CAGGGTACATGGTGGTGCC; CD3 (forward): GGCTGTCCTCATCCTGGCTATCAT; CD3 (reverse): ACTGGTTTCCTTGAAGGTGGCTGT; CD14 (forward): ACTCCCTCAATCTGTCGTTCGCTG; CD14 (reverse): CTGAAGCCAAGGCAGTTTGAGTCC; SP-A (forward): TCTTTGGATGCCAAC TCA GC; SP-A (reverse) CTTTATTCAGCTCAGGGGTG. All primers were synthesized by MWG-Biotech (MWG-Biotech AG, Ebersberg, Germany). Target cDNA was amplified using a three-temperature PCR and an automated thermocycler (Biometra, Göttingen, Germany) according to REILING et al. [17] with primer pairs for NOS2, and according to MURRAY et al. [18] with primer pairs for CD3 and CD14, respectively. PCR conditions for $\beta$-actin amplification included: $95^{\circ} \mathrm{C}$ for $1 \mathrm{~min}, 57^{\circ} \mathrm{C}$ for $1 \mathrm{~min}$ and $72^{\circ} \mathrm{C}$ for $1 \mathrm{~min}$ $30 \mathrm{~s}$; and for SP-A: $94^{\circ} \mathrm{C}$ for $1 \mathrm{~min}, 54^{\circ} \mathrm{C}$ for $1 \mathrm{~min}$, $72^{\circ} \mathrm{C}$ for $1 \mathrm{~min} 30 \mathrm{~s}$, and $72^{\circ} \mathrm{C}$ (terminal extension) for $15 \mathrm{~min}$. The numbers of cycles were the same for NOS2, CD3, CD14, SP-A, and $\beta$-actin (35 cycles). PCR products (length: $462 \mathrm{bp}, 517 \mathrm{bp}, 341 \mathrm{bp}$, $622 \mathrm{bp}$, and $309 \mathrm{bp}$ for NOS2, CD3, CD14, SP-A, and $\beta$-actin respectively) were electrophoresed on $1.5 \%$ agarose (Gibco BRL) gels and stained with ethidium bromide. Gel analysis was performed densitometrically with the "Gel Doc 2000" gel documentation system and "Quantity One 4.0.3" software (Bio-Rad Laboratories, Hercules, CA, USA). To assure the identity of the PCR-amplified fragments, the size of 
each amplified mRNA fragment was compared with deoxyribonucleic (DNA) standards (100 bp DNA Ladder; Gibco BRL) electrophoresed on the same gel. Additionally, the NOS2 specificity of the PCR product was verified by comparing their sequence data with published sequences. The NOS2-specific primers used in the RT-PCR were intron-spanning and therefore genomic DNA contamination did not influence the PCR results [17].

\section{Immunocytochemistry}

AM and AEC-II $\left(2.5 \times 10^{5}\right.$ cells $)$ were plated in duplicate chambers of an eight-chamber glass slide (Flexiperm-Slide, W.C. Heraeus GmbH, Hanau, Germany) and cultured in culture medium, in the presence or absence of IFN- $\gamma\left(50 \mathrm{U} \cdot \mathrm{mL}^{-1}\right)$, or a combination of cytokines (TNF- $\alpha\left(5 \mathrm{ng} \cdot \mathrm{mL}^{-1}\right)$, IFN- $\gamma$ $\left(50 \mathrm{U} \cdot \mathrm{mL}^{-1}\right)$ and IL-1 $\left.\beta\left(50 \mathrm{U} \cdot \mathrm{mL}^{-1}\right)\right)$ for $18 \mathrm{~h}$ at $37^{\circ} \mathrm{C}$. BAL cells were incubated under the same conditions. The cytocentrifuge slides were prepared with AEC-II, AM and BAL cell preparations without previous culture of the cells. Slides were washed in PBS and cells were fixed with $3.7 \%$ paraformaldehyde in PBS for $10 \mathrm{~min}$. After fixation, slides were washed three times in PBS/0.1\% saponin. Endogenous peroxidase was blocked by incubation with $0.3 \%$ hydrogen peroxide $/ 0.02 \%$ sodium azide for $15 \mathrm{~min}$, followed by a further incubation with $10 \%$ normal goat serum in $\mathrm{PBS} / 0.1 \%$ saponin for $10 \mathrm{~min}$. Between the various steps the slides were washed in $\mathrm{PBS} / 0.1 \%$ saponin at room temperature. The slides were incubated with a murine monoclonal anti-human NOS2 antibody (Transduction Laboratories, Lexington, KY, USA) at $4 \mu \mathrm{g} \cdot \mathrm{mL}^{-1}$ in $\mathrm{PBS} / 0.1 \%$ saponin for $2 \mathrm{~h}$ at room temperature. Control slides were incubated in PBS/ $0.1 \%$ saponin alone. After washing and incubation with a biotinylated goat anti-mouse IgG antibody (Jackson ImmunoResearch Laboratories, West Grove, PA, USA) for $30 \mathrm{~min}$, and with streptavidin horseradish peroxidase (Zymed Labs, South San Francisco, CA, USA) for $30 \mathrm{~min}$, the slides were treated with diaminobenzidine in PBS, counterstained with haematoxylin, mounted in glycerol gelatine and coverslipped. A549 cells stimulated with IFN- $\gamma$ $\left(100 \mathrm{U} \cdot \mathrm{mL}^{-1}\right)$ and a mixture of cytokines for $18 \mathrm{~h}$ were used as positive controls. Slides with the primary antibodies omitted were used as negative controls.

\section{Western blot analysis for nitric oxide synthase-2}

AEC-II or A549 cells $\left(5 \times 10^{6}\right)$ that had been incubated with or without appropriate stimuli were removed from flasks by treatment with trypsin/EDTA solution for $10 \mathrm{~min}$ at $37^{\circ} \mathrm{C}$, washed in PBS and resuspended in $0.2 \mathrm{~mL}$ of a lysis buffer $(50 \mathrm{mM}$ Tris $\mathrm{HCl}$, pH 7.6/100 mM NaCl/2 mM EDTA/2 mM EGTA $/ 0.1 \%$ of Triton $\mathrm{X} / 1 \%$ of protease-inhibitor cocktail (Sigma, St. Louis, MO, USA)) and lysed for 30 min on ice. Cell debris was removed by centrifugation at $13000 \times g$ for $15 \mathrm{~min}$. NOS2 protein was enriched by adenosine $2^{\prime} 5^{\prime}$-diphosphate-agarose
(Sigma, Deisenhofen, Germany). Aliquots of this enriched fraction were resolved by sodium dodecylsulphate gel electrophoresis (SDS-PAGE) (10\% acrylamide) and transfered onto nitrocellulose membranes (Amersham Pharmacia biotech, Little Chalfont, UK) by using a semi-dry technique (Hoefer Semi-Dry Transfer Unit, Amersham Pharmacia biotech). The membranes were labelled with monoclonal mouse anti-NOS2 antibodies, as suggested by the supplier (Transduction Laboratories, Lexington, KY, USA). The blots were developed using the enhanced chemiluminescence (ECL, Amersham Pharmacia) technique according to the manufacturer's instructions.

\section{In situ hybridization}

Paraffin-embedded lung-tissue samples were cut from the same surgical specimens as described earlier and used for in situ hybridization (ISH). These tissue samples showed normal architecture with few intraalveolar macrophages and oedema. The cDNA probe corresponding to the NOS2 gene was produced by PCR as described earlier, filtered through Centri-Sep spin columns (Applied Biosystems, Foster City, CA, USA), and labelled with digoxigenin (Dig) following the manufacturer's instructions (Dig-High-Prime, Roche, Germany). After deparaffinization, ISH was carried out overnight and, after washing at high stringency, detection was performed by application of Anti-Dig/alkaline-phosphatase-conjugate and newfuchsin as a substrate for the alkaline phosphatase [19]. For the negative control, sections were hybridized with the hybridization buffer in the absence of labelled cDNA probes. The specificity of the hybridization signal was confirmed by treating preparations with ribonuclease (RNase) before hybridization.

\section{Nitritelnitrate determination}

Total NO-products were determined by a Nitrate/ Nitrite colourimetric assay kit (Cayman Chemical, Ann Arbor, MI, USA) according to the suggestions of the supplier. This test employs a Griess reaction after enzymatic conversion of $\mathrm{NO}_{3}^{-}$into $\mathrm{NO}_{2}^{-}$.

\section{Statistical analysis}

Data are expressed as mean \pm SEM. Statistical comparisons were made by analysis of variance (ANOVA) with post hoc Fisher's protected least significant difference (PLSD) for each agent separately. Probability values were considered significant if they were $<0.05$.

\section{Results}

Characteristics of isolated alveolar epthelial cells and alveolar macrophages

To minimize cellular contamination, human AECII isolated by three steps of purification, as described 
in the Materials and methods section, were used. After the final step of MACS purification, the AEC-II preparations included in this report were free of CD14+ and CD3+ cells as determined by immunocytochemistry. A total of $97 \pm 1.9 \%$ of cells were identified as AEC-II by the presence of dark blue inclusions as revealed by modified Papanicolaou staining and $94 \pm 1.1 \%$ of cells were positive for alkaline phosphatase (fig. 1a and 1b). All RNA samples isolated from these AEC-II preparations contained SP-A mRNA but no CD3 and CD14 mRNA as determined by RT-PCR (fig. 1d).

The autologous AM, which were obtained from the same lung tissue samples and purified by MACS "positive" selection, contained $85 \%$ of CD14+cells, and were contaminated with $6.4 \pm 4.3 \%$ of CD3+cells and $7.8 \pm 3.6 \%$ of AEC-II. These data were confirmed by immunoperoxidase staining with monoclonal antibodies directed against human CD14 and CD3 surface antigens (data not shown), alkaline phosphatase staining (fig. 1c) and by RT-PCR for CD3 and SP-A
mRNA (fig. 1d). Additional evaluation of these cell preparations under a light microscope revealed that CD3+ cells and AEC-II displayed a strong capability to adhere on the AM surface (data not shown), and therefore contaminated the CD14+ cell populations.

Cells retrieved from BAL samples disclosed higher percentages of AM $(93.3 \pm 2.7 \%, \mathrm{n}=5)$ which were contaminated with $3.2 \pm 1.8 \%$ lymphocytes, $1.8 \pm 0.9 \%$ neutrophils, but free of AEC-II as shown by SP-A mRNA analysis (fig. 1d), henceforth referred to as BAL-AM. These cell populations were not purified, so that introduction of artefacts in experimental conditions was avoided.

Nitric oxide synthase type-2 messenger ribonucleic acid expression in aveolar epithelial cells type II and alveolar macrophages isolated from lung tissue samples

RT-PCR with RNA samples from freshly isolated noncultured AEC-II as well as from cultured
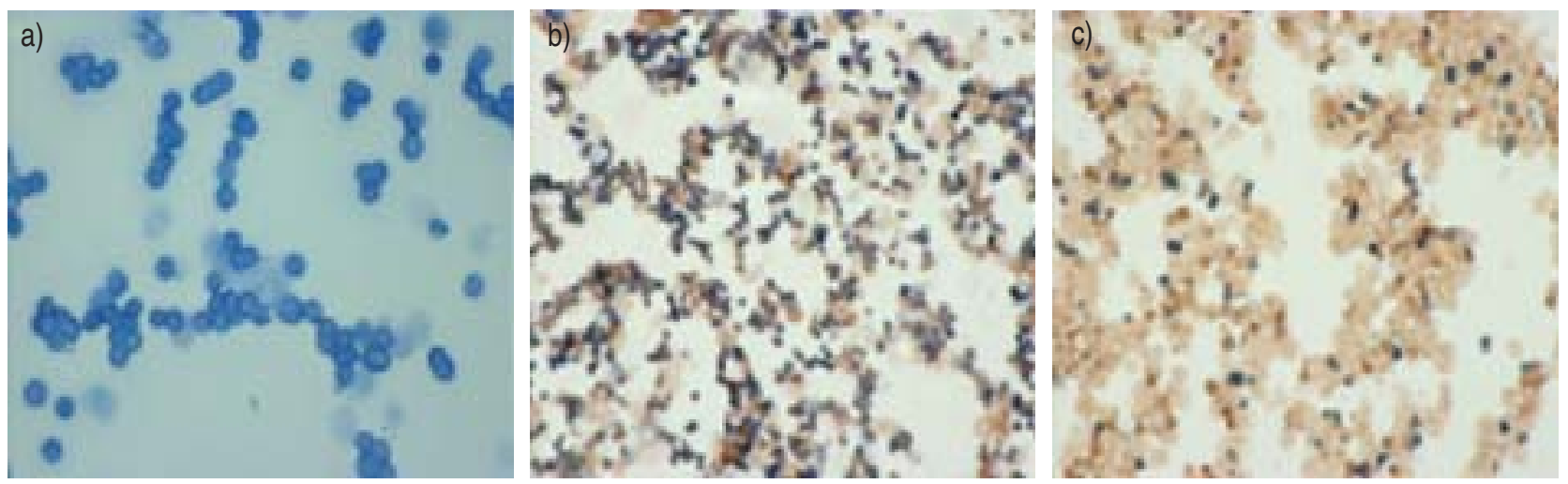

d)

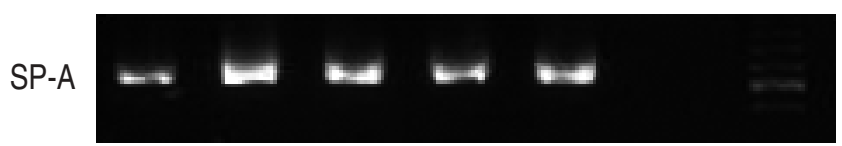

bp

622
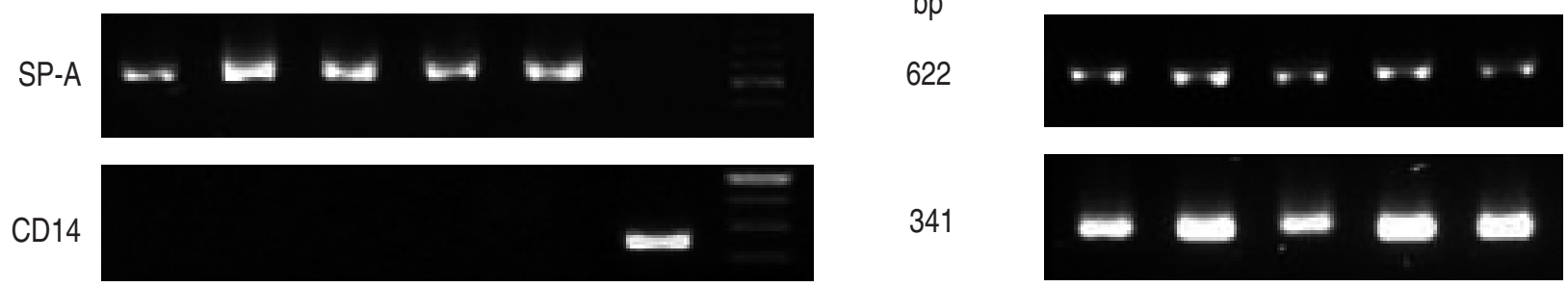

CD3
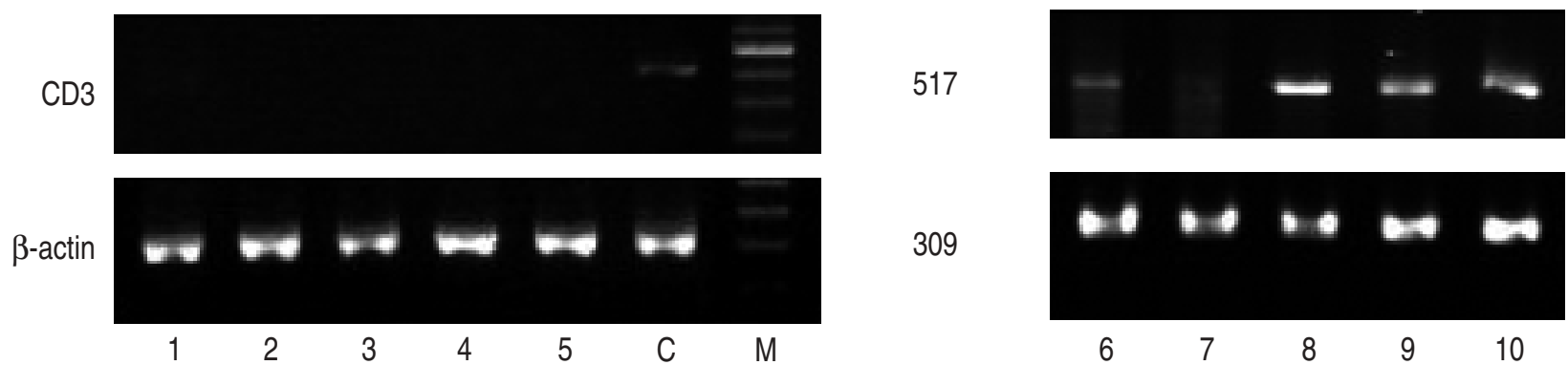

309

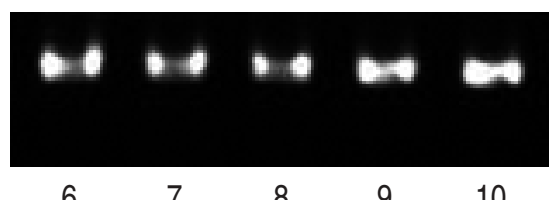

Fig. 1.-Photomicrographs of freshly isolated human alveolar epithelial cells type II (AEC-II) stained with a) modified Papanicolaou stain, and b) for alkaline phosphatase (AP), and counterstained with $0.1 \%$ neutral red. c) Alveolar macrophages (AM) freshly isolated from lung tissue samples and stained for expression of AP. d) The results of reverse-transcriptase polymerase chain reaction (RT-PCR) product analysis with ribonucleic acid (RNA) from five freshly isolated AEC-II and AM preparations (lanes 1-5 and 6-10 respectively) and specific primers for surfactant protein A (SP-A), CD14, CD3, and $\beta$-actin. Lane C shows the results of RT-PCR with RNA isolated from one noncultured human bronchoalveolar lavage cell preparation used as positive control for CD3 and CD14, and as negative control for SP-A. 
a)

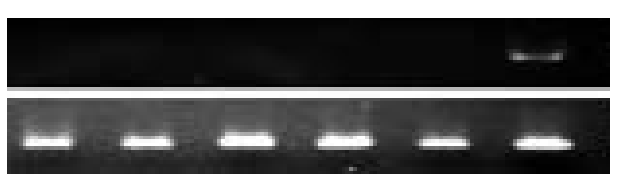

bp

462 NOS2

$309 \beta$-actin

b)

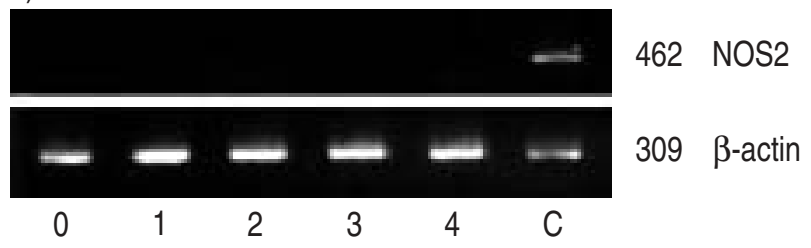

c)

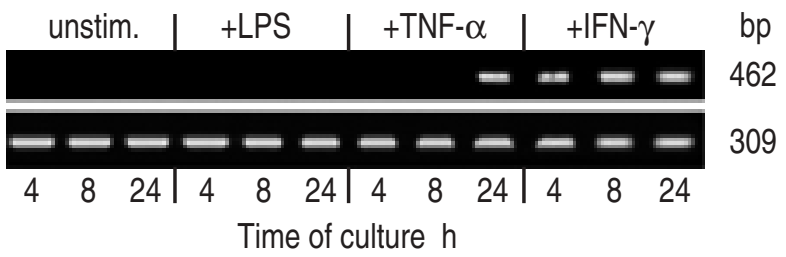

Fig. 2.-Nitric oxide synthase-2 (NOS2) messenger ribonucleic acid (mRNA) analysis by reverse-transcriptase polymerase chain reaction (RT-PCR) of noncultured (lane 0) and cultured alveolar epithelial cells type-II (AEC-II), alveolar macrophages (AM), and A549 cells. Cells were cultured without (lane 1) or with tumour necrosis factor (TNF)- $\alpha\left(5 \mathrm{ng} \cdot \mathrm{mL}^{-1}\right.$; lane 2$)$, interferon (IFN)- $\gamma$ $\left(50 \mathrm{U} \cdot \mathrm{mL}^{-1}\right.$; lane 3$)$ or interleukin (IL) $-1 \beta\left(50 \mathrm{U} \cdot \mathrm{mL}^{-1}\right.$; lane 4) for $24 \mathrm{~h}$. a) Representative images of NOS2 mRNA expression in AEC-II are from one of five identical experiments, and b) from one of ten identical experiments with AM isolated from lung tissue samples. c) Time/course experiment after the seventh passage shows the effect of lipopolysaccharide (LPS) or cytokinestimulation on NOS2 mRNA expression by A549 cells after 4, 8, and 24 h. C: positive control.

unstimulated and cytokine-stimulated cells did not reveal the presence of any NOS2 mRNA (fig. 2a). NOS2 gene expression could not be detected in cells stimulated with IFN- $\gamma\left(10,50\right.$, and $\left.100 \mathrm{U} \cdot \mathrm{mL}^{-1}\right)$, with LPS $\left(1 \mu \mathrm{g} \cdot \mathrm{mL}^{-1}\right)$, TNF- $\alpha\left(1,5\right.$, and $\left.10 \mathrm{ng} \cdot \mathrm{mL}^{-1}\right)$ or $\operatorname{IL}-1 \beta\left(10,50\right.$, and $\left.100 \mathrm{U} \cdot \mathrm{mL}^{-1}\right)$ for $4,8,16$, and $24 \mathrm{~h}$, and with the combination of the three cytokines at the same time periods (data not shown). All RNA samples isolated from these cultures were positive for SP-A and intensities of the bands were not different in unstimulated and cytokine-stimulated cells over all time periods of culture (data not shown). In $\mathrm{AM}$ isolated from lung tissue samples there was no detectable NOS2 mRNA in noncultured, unstimulated or in cultured cytokine-stimulated cells at different time periods and stimulation protocols (fig. 2b).

In contrast to AEC-II and AM, the stimulation of A549 cells with IFN- $\gamma$ or TNF- $\alpha$ for $24 \mathrm{~h}$ resulted in an upregulation of NOS2 mRNA expression (fig. 2c). Stimulation of AM, AEC-II, or A549 cells with LPS alone ( 1 or $10 \mu \mathrm{g} \cdot \mathrm{mL}^{-1}$ ) did not lead to the upregulation of NOS2 mRNA expression in any of the experimental conditions tested (fig. 2c).

Another pattern of NOS2 mRNA expression was found when AEC-II were stimulated with LPS or

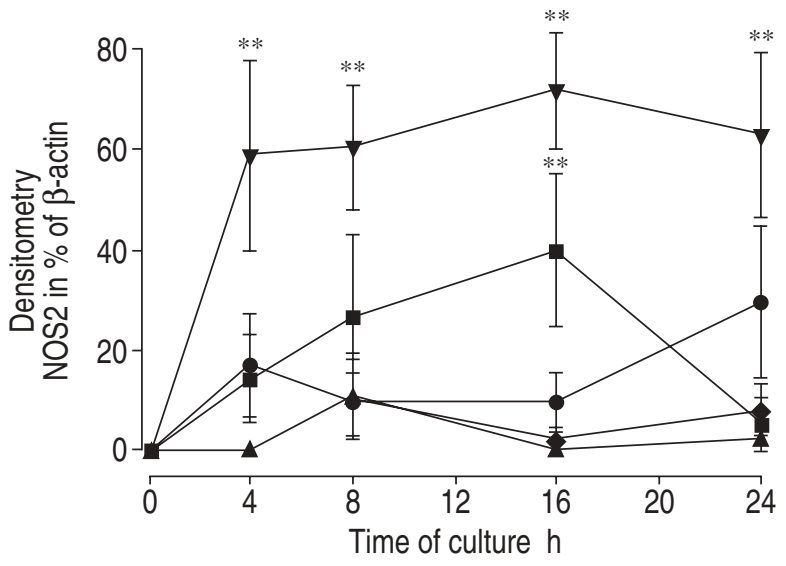

Fig. 3.-Time course of reverse-transcriptase polymerase chain reaction (RT-PCR) for nitric oxide synthase-2 (NOS2) messenger ribonucleic acid (mRNA) with samples of ribonucleic acid (RNA) isolated from five alveolar macrophages (AM)-alveolar epithelial cells type-2 (AEC-II) co-cultures. AEC-II with $10 \%$ of AM were cultured without $(\boldsymbol{\Delta})$ or with tumour necrosis factor- $\alpha(\boldsymbol{\bullet})$, interferon- $\gamma(\boldsymbol{\nabla})$, interleukin-1 $\beta$ ( $)$, or lipopolysaccharide $(\mathbf{0})$ for $0,4,8,16$ and $24 \mathrm{~h}$. The PCR products from each culture were individually quantified, and data are presented as the mean percentages of $\beta$-actin density $\pm \operatorname{SEM}(n=5)$. **: $p<0.01$ as compared with unstimulated cells.

cytokines for $4,8,16$ and $24 \mathrm{~h}$ in the presence $10 \%$ of autologous AM. As shown in figure 3, stimulation with IFN- $\gamma\left(50 \mathrm{U} \cdot \mathrm{mL}^{-1}\right)$ and IL-1 $\beta\left(50 \mathrm{U} \cdot \mathrm{mL}^{-1}\right)$ leads to a statistically significant up-regulation of NOS2 mRNA expression in a dose- and timedependant manner. There were lower NOS2 mRNA expression levels after stimulation with $10 \mathrm{U} \cdot \mathrm{mL}^{-1}$ compared to $50 \mathrm{U} \cdot \mathrm{mL}^{-1}$ or $100 \mathrm{U} \cdot \mathrm{mL}^{-1}$ of IFN- $\gamma$ at the earlier time points of AM-AEC-II co-cultures (data not shown). Stimulation with $100 \mathrm{U} \cdot \mathrm{mL}^{-1}$ resulted in lower message levels compared to $50 \mathrm{U} \cdot \mathrm{mL}^{-1}$ of IFN- $\gamma$ after $24 \mathrm{~h}$, and the increase of cytokine concentrations $>100 \mathrm{U} \cdot \mathrm{mL}^{-1}$ disclosed an inhibitory effect on NOS2 expression (data not shown). Therefore a concentration of $50 \mathrm{U} \cdot \mathrm{mL}^{-1}$ IFN- $\gamma$ and a 24-h cell-culture period for further experiments with AM-AEC-II co-cultures was used. No significant amounts of NOS2 mRNA were found in freshly isolated cells, in cells without additives and in cells stimulated with TNF- $\alpha$ or LPS (fig. 3). Thus, the level of NOS2 mRNA expression in AEC-II or AM appeared to depend on the presence of both types of cells together with IFN- $\gamma$.

In separate experiments, highly purified AEC-II were co-cultured with autologous AM at different percentages $(2.5,5,10$ and $15 \%)$ either in the presence or absence $50 \mathrm{U} \cdot \mathrm{mL}^{-1}$ of IFN- $\gamma$ for $24 \mathrm{~h}$. As shown in figures $4 \mathrm{a}$ and $4 \mathrm{~b}$, the IFN- $\gamma$-induced NOS2 mRNA expression in AM-AEC-II co-cultures was dependant on the presence of AM. Levels as low as $5-15 \%$ of $A M$ were sufficient to detect their NOS2 mRNA after IFN- $\gamma$ stimulation, and further increasing the percentage of AM in AM-AEC-II co-cultures did not lead to higher NOS2 mRNA expression levels (fig. 4). As shown earlier, the presence of $5-10 \%$ of AEC-II in the autologous AM population was not enough to induce NOS2 mRNA 
a)
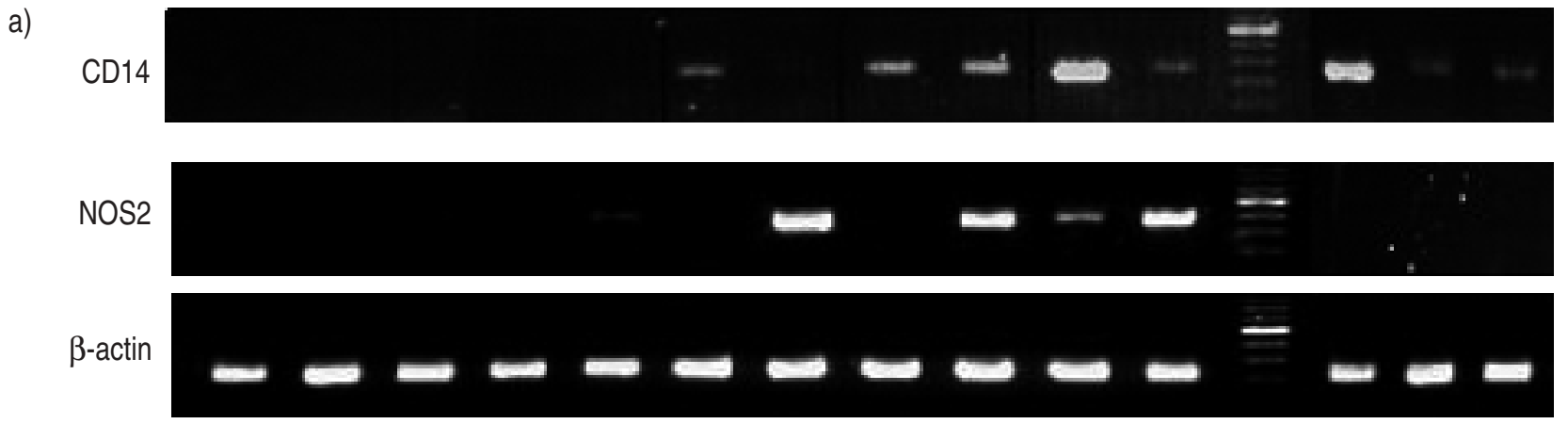

\begin{tabular}{|c|c|c|c|c|c|c|c|c|c|c|c|c|c|c|c|}
\hline Culture $24 \mathrm{~h}$ & - & + & + & + & + & + & + & + & + & + & + & & - & + & + \\
\hline AEC-II \% & 100 & 100 & 100 & 97.5 & 97.5 & 95 & 95 & 90 & 90 & 85 & 85 & & 0 & 0 & 0 \\
\hline IFN- $\gamma$ & - & - & + & - & + & - & + & - & + & - & + & M & - & - & + \\
\hline AM \% & 0 & 0 & 0 & 2.5 & 2.5 & 5 & 5 & 10 & 10 & 15 & 15 & & 100 & 100 & 100 \\
\hline
\end{tabular}

b)

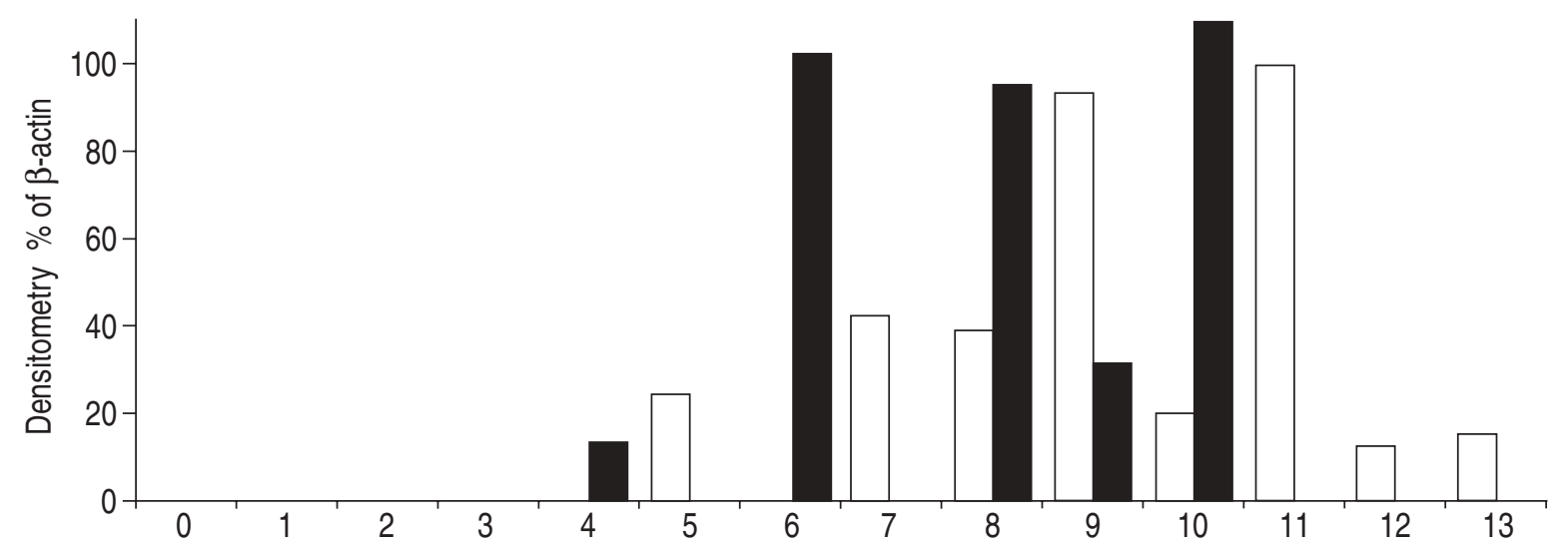

Fig. 4. - Nitric oxide synthase-2 (NOS2) and CD14 messenger ribonucleic acid (mRNA) expression in alveolar epithelial cells type-II (AEC-II) co-cultured with autologous alveolar macrophages (AM) $(2.5-15 \%)$ in the presence or absence of $50 \mathrm{U} \cdot \mathrm{mL}^{-1}$ interferon- $\gamma$ for 24 h. a) Representative gel images from one of two identical experiments. b) Densitometric analysis of gel bands shown in a ( $\square$ : CD14; E: NOS2). Lanes 0 and 11, freshly isolated AEC-II and AM respectively; lanes 1-10, unstimulated and interferon (IFN)- $\gamma$ stimulated AEC-II with AM; lanes 11, 12 and 13, unstimulated and IFN- $\gamma$-stimulated AM respectively. M: molecular marker.

expression in IFN- $\gamma$-stimulated cultures (fig. 1 and $2 b$ ). As expected, the levels of CD14 mRNA in unstimulated co-cultures increased with increasing percentage of AM, whereas the addition of IFN- $\gamma$ markedly reduced its accumulation in the AM-AEC-II co-cultures (fig. 4). This is in accordance with the observations by LANDMANn et al. [20] and PAYNE et al. [21] that IFN- $\gamma$ reduces CD14 protein expression in human monocytes. Highly purified AEC-II preparations in these experiments were free of CD14 mRNA (fig. 1d) and, to the best of the authors' knowledge, no CD14 mRNA or protein expression in human AECII has been described. No changes in SP-A mRNA were detected (data not shown).

\section{Immunocytochemistry and in situ hybridization}

A549 cells stimulated with IFN- $\gamma$ or a cytokine mixture expressed clear-cut NOS2 immunoreactivity as compared to unstimulated cells (fig. $5 \mathrm{a}$ and b). In contrast, a weak immunoreactivity for human NOS2 was seen in a small proportion of noncultured AM and it decreased after stimulation with IFN- $\gamma$ or with a cytokine combination for $18 \mathrm{~h}$ (fig. $5 \mathrm{c}$ and $5 \mathrm{~d}$ ). No NOS2 immunoreactivity was detected in unstimulated or cytokine-stimulated AEC-II, which were cultured alone or with $10-15 \%$ of autologous AM (fig. 5e and $\mathrm{f}$ ). Immunostaining of BAL-AM resulted in a moderate immunoreactivity seen in $10-25 \%$ of noncultured cells (fig. $5 \mathrm{~g}$ ). Culture of these cells in the presence of IFN- $\gamma$ or a cytokine combination resulted in the same NOS2 staining pattern as was seen in the cells cultured without cytokines for $18 \mathrm{~h}$. In most BAL-AM preparations a decreasing immunoreactivity was seen after 18 -h culture (fig. $5 \mathrm{~g}$ and $5 \mathrm{~h}$ ). Slides labelled with buffer or control Ig-G did not show immunostaining in both AM and A549 cultures (data not shown). In situ hybridization using Diglabelled DNA probes detected specific signals for NOS2 mRNA mainly in intra-alveolar macrophages in all lung tissue preparations included in the present report. AM were identified by their size and localization in the lumen of the alveoli in close proximity to alveolar epithelium. In contrast, no positive signals for NOS2 mRNA were detected in alveolar epithelium, 

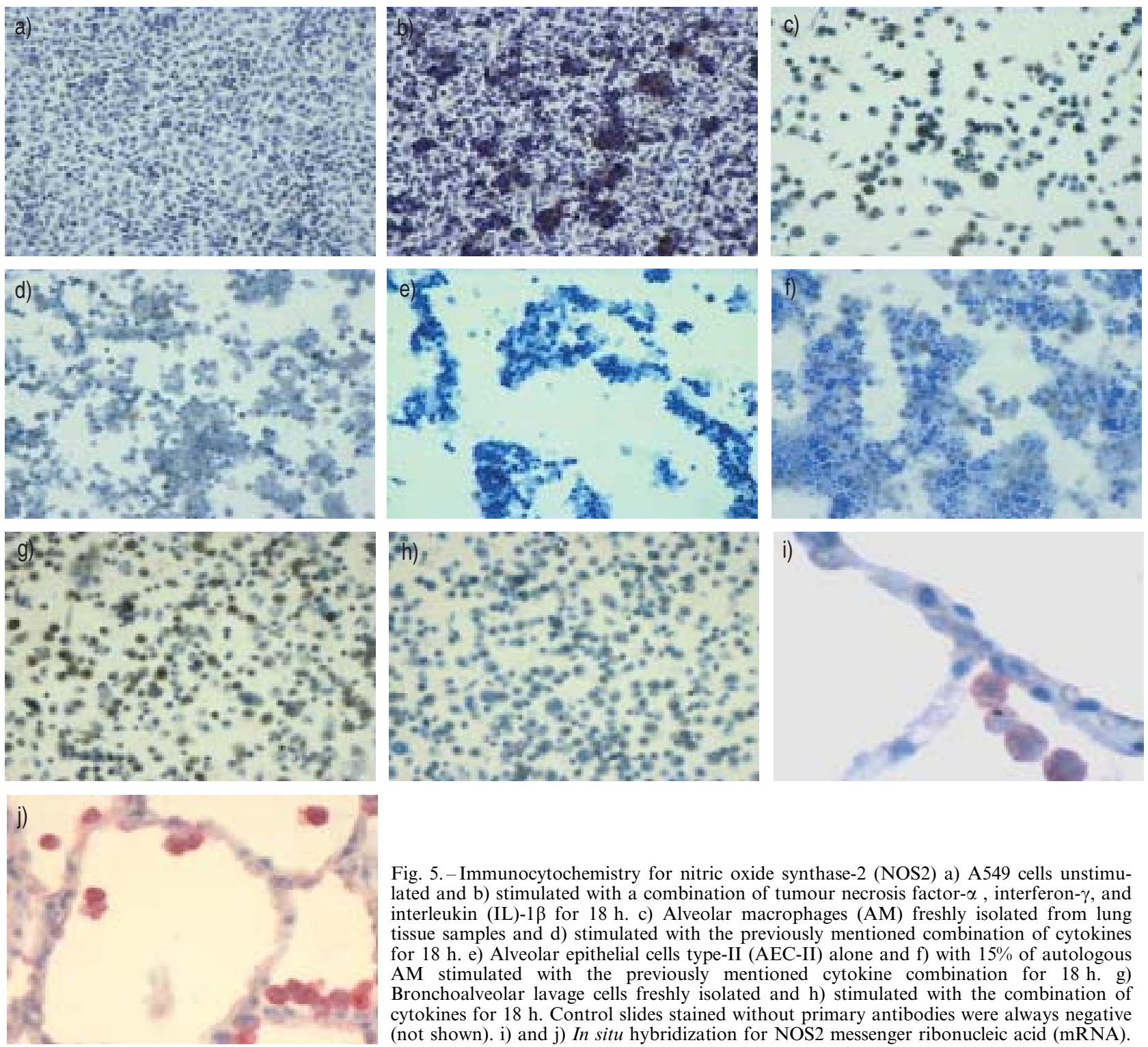

Fig. 5. - Immunocytochemistry for nitric oxide synthase-2 (NOS2) a) A549 cells unstimulated and b) stimulated with a combination of tumour necrosis factor- $\alpha$, interferon- $\gamma$, and interleukin (IL)-1 $\beta$ for $18 \mathrm{~h}$. c) Alveolar macrophages (AM) freshly isolated from lung tissue samples and d) stimulated with the previously mentioned combination of cytokines for $18 \mathrm{~h}$. e) Alveolar epithelial cells type-II (AEC-II) alone and f) with $15 \%$ of autologous AM stimulated with the previously mentioned cytokine combination for $18 \mathrm{~h}$. g) Bronchoalveolar lavage cells freshly isolated and $\mathrm{h}$ ) stimulated with the combination of cytokines for $18 \mathrm{~h}$. Control slides stained without primary antibodies were always negative (not shown). i) and j) In situ hybridization for NOS2 messenger ribonucleic acid (mRNA).

including AEC-II, which were typically localized at alveolar corners (fig. $5 \mathrm{i}$ and $5 \mathrm{j}$ ). Specific signals were not detected in control preparations, in which specific DNA probes were substituted by hybridization buffer alone, or treated with RNase before hybridization (not shown).

\section{Western blot analysis}

Western blot analysis of crude cell lysates of AECII, AM, or AM/AEC-II co-cultures revealed no positive NOS2 protein signals. After enrichment of the cell lysates by $2^{\prime} 5^{\prime}$-ADP-agarose, NOS2 protein could be detected in IFN- $\gamma$-stimulated AM-AEC-II co-cultures containing 10\% AM (fig. 6a). Again, no NOS2 protein was found in lysates from unstimulated co-cultures or in either unstimulated or IFN- $\gamma$ stimulated AEC-II, whereas an equivalent amount of lysates from LPS/IFN- $\gamma$-stimulated murine cell line RAW264.7 demonstrated positive signal of protein (fig. 6a). These NOS2 positive control lysates were provided by Transduction Laboratories (Lexington, KY, USA).

\section{Nitratelnitrite in alveolar epithelial cells type IIlalveolar macrophages supernatants}

Supernatants from purified AM contained more $\mathrm{NO}_{\mathrm{x}}$ compared to supernatants from purified AEC-II (fig. 6b). Stimulation of purified AM with IFN- $\gamma$ did not significantly alter the $\mathrm{NO}_{\mathrm{x}}$ concentrations in the supernatants. In the AM-AEC-II co-culture supernatants only a marginal increase in the overall $\mathrm{NO}_{\mathrm{x}}$ content compared to AEC-II cultures could be detected (fig. 6b). 
a)

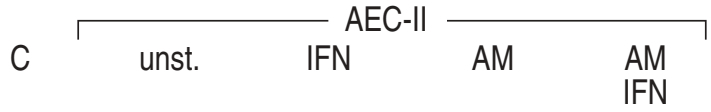
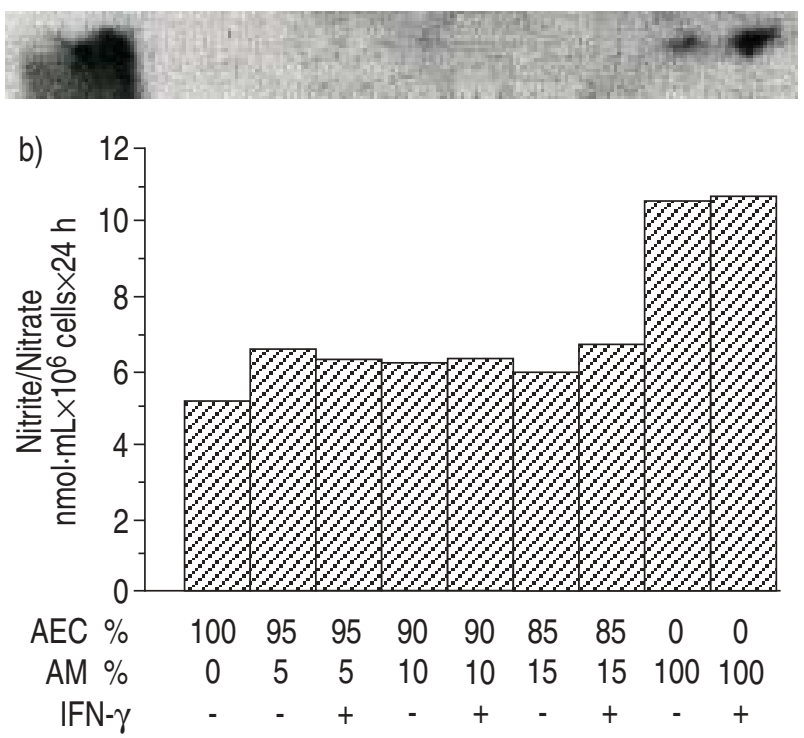

Fig. 6. -a) Western blot analysis of nitric oxide synthase-2 (NOS2) production. No NOS2 protein was detected in the cell lysates from unstimulated (unst.), interferon (IFN)- $\gamma$-stimulated $\left(50 \mathrm{U} \cdot \mathrm{mL}^{-1}\right)$ alveolar epithelial cells (AEC)-II cultures, and unstimulated alveolar macrophages (AM)-AEC-II co-cultures after $24 \mathrm{~h}$, whereas positive control lysate (C) and lysates from IFN- $\gamma$ stimulated AM-AEC-II co-cultures containing $10 \%$ AM show clear signals of NOS2 protein. b) In supernatants from AEC-II cultures minor amounts of total $\mathrm{NO}_{\mathrm{x}}$ were detectable and in addition $5-15 \%$ of $\mathrm{AM}$ increased this overall $\mathrm{NO}_{\mathrm{x}}$ content only marginally, whereas purified $\mathrm{AM}$ generated considerably more $\mathrm{NO}_{\mathrm{x}}$, and stimulation with IFN- $\gamma$ does not significantly influence the generation of $\mathrm{NO}_{\mathrm{x}}$ in all cases. Bars represent means of duplicate determinations from one representative experiment out of three.

Nitric oxide synthase-2 messenger ribonucleic acid expression in cells retrieved from bronchoalveolar lavage samples

To exclude any effect of the isolation procedure on NOS2 mRNA expression by human AM from the lung tissue samples, experiments with BAL-AM obtained from subjects retrospectively free of any systemic or lung diseases were performed. These cells were cultured under the same experimental conditions as AEC-II and AM from the lung tissue samples. However, no NOS2 mRNA could be found in noncultured, unstimulated or IFN- $\gamma$-stimulated BALAM. In addition, neither LPS (1 or $10 \mu \mathrm{g} \cdot \mathrm{mL}^{-1}$ ) nor a mixture of pro-inflammatory cytokines, or a combination of both resulted in the induction of NOS2 mRNA (data not shown). However, RT-PCR with specific primers for NOS2 yielded the expected band of $462 \mathrm{bp}$ from NOS2 positive controls (IFN- $\gamma$ stimulated A549 cells), and all RNA samples were positive for $\beta$-actin mRNA (data not shown).

In order to evaluate whether SP-A might be the AEC-II-derived factor able to enhance IFN- $\gamma$-induced cell responses, SP-A at different concentrations $\left(1-100 \mu \mathrm{g} \cdot \mathrm{mL}^{-1}\right)$ was added in the presence or absence of IFN- $\gamma$ to BAL-AM. Neither SP-A alone nor a combination of IFN- $\gamma$ and SP-A at different concentrations resulted in the induction of NOS2 mRNA in BAL-AM (data not shown).

\section{Discussion}

There is growing evidence that certain forms of acute and chronic pulmonary inflammation such as bronchial asthma [22], ARDS [5], IPF [3, 9], tuberculosis [1], and sarcoidosis [2] are associated with the upregulation of pulmonary NOS2 expression. In addition, an increase of NO in exhaled air is measured in these diseases. Although the sources of NO under these pathophysiological conditions are not completely clarified, it is generally thought that AM and airway epithelium represent the major sources.

Human AM contain NOS2 protein and can express the NOS2 gene. The accumulation of NOS2 protein has been documented in AM isolated from patients with active pulmonary tuberculosis [8], lung cancer [4], and ARDS [3]. In addition, it has been shown that AM in lung sections from patients with IPF [9], chronic obstructive pulmonary disease (COPD) [23] and sarcoidosis [2] display strong immunoreactivity for NOS2 protein in situ. However, many attempts to induce NOS2 mRNA expression and/or NO production by human AM in vitro failed [7, 24, 25]. As shown in the present investigation, $\mathrm{AM}$ isolated from lung tissue samples exhibited immunoreactive NOS2 protein ex vivo and its level was preserved or slightly decreased during 18-h culture periods with or without stimuli such as pro-inflammatory cytokines. In addition, AM, but not AEC-II, were strongly positive for NOS2 mRNA in situ on lung tissue preparations included in this report. However, neither lung tissue derived nor BAL retrieved human AM express detectable NOS2 mRNA levels in the absence or presence of pro-inflammatory cytokines or LPS in vitro. Interestingly, these findings corroborate with previously published results, stating that AM retrieved from BAL cells of normal donors and patients with pulmonary tuberculosis or primary lung cancer contained NOS2 protein ex vivo, but no NOS2 mRNA $[4,7,8,24]$. This was true for cells, which were stimulated by IFN- $\gamma$, LPS or mycobacteria in vitro [8]. It can be concluded that the alveolar microenvironment is a critical factor for accumulation and/or stability of NOS2 mRNA in human AM.

There are many factors including direct cell-cell contacts and soluble mediators that influence NOS2 expression of human AM. A recent study indicates that human SP-A enhances production of NO and NOS2 protein expression in rat AM stimulated with IFN- $\gamma$ or with LPS/IFN- $\gamma$ combinations. SP-A itself did not affect production of NO or NOS2 protein expression in rat AM [12]. In contrast to rat $\mathrm{AM}$, the present results demonstrate that neither IFN- $\gamma$ alone nor the combination of IFN- $\gamma$ with SP-A induced NOS2 gene transcription in human BAL-AM in monoculture. However, these cells, as well as AM isolated from lung tissue samples, contained immunoreactive NOS2 protein and its expression levels decreased after 18-h culture with or 
without pro-inflammatory cytokine-stimulation. These unexpected differences between NOS2 mRNA and protein expression levels in human AM can be explained by a very low stability of NOS 2 mRNA in combination with a long half-life time of the protein. Regulatory processes acting on NOS 2 mRNA stability and protein half-life have been identified in human articular chondrocytes and mouse peritoneal macrophages [26, 27].

The requirements for the induction of NOS2 gene transcription in human monocytes/macrophages depend on the origin of the cells [7, 28]. Using protocols, which elicit NOS2 mRNA expression in peripheral blood derived macrophages [28] NOS2 mRNA in human AM irrespective of source and in vitro stimulation could not be detected (fig. 2b). The authors hypothesized that NOS2 mRNA expression and its steady-state levels in human AM depend on in situ conditions within the alveolar space, and this may explain the conflicting results of NOS2 mRNA and protein expression in vivo and in vitro. Following these observations the authors were stimulated to evaluate whether the presence of human AEC-II is the factor inducing NOS2 expression in human AM.

The in vivo stimulus for NOS2 expression and NO production by human AM has not been elucidated. However, the close proximity of these cells and AEC-II within the alveoli suggests that AEC-derived products as well as direct cell-cell contacts might be involved. The present results demonstrate that human AM and AEC-II, when stimulated separately by IFN- $\gamma$ do not express NOS 2 mRNA within a $24-h$ culture period, whereas the co-culture of these cells in the presence of IFN- $\gamma$ is the most potent factor for the induction and steady-state level of NOS2 mRNA. These findings indicate that NOS2 mRNA can be expressed in IFN- $\gamma$-stimulated AM-AEC-II cocultures at a percentage of AM as low as $2.5 \%$, and the level of NOS2 mRNA increased with the increasing percentage of AM in AM-AEC-II co-cultures up to $10 \%$ of cells. Further increase of the AM-AEC-II ratio did not lead to an increase in NOS2 mRNA accumulation. AM obtained from lung tissue were contaminated with $5-10 \%$ of AEC-II as indicated in the Results section (fig. 1c and 1d). However, despite the presence of AEC-II in these AM preparations, neither unstimulated nor IFN- $\gamma$-stimulated cells express NOS2 mRNA (fig. $2 b$ and 4). Accordingly with NOS2 mRNA data, the levels of NOS2 protein and $\mathrm{NO}_{\mathrm{x}}$ concentrations also increased with the increasing of AM percentage in the IFN- $\gamma$-treated co-cultures. Although there were no differences between total $\mathrm{NO}_{\mathrm{x}}$ concentrations in supernatants from unstimulated and IFN- $\gamma$-stimulated AM-AEC-II co-cultures, a small amount of NOS2 protein was only detected in cell lysates from the latter (fig. 6a). In addition, immunostaining of AEC-II and AM in co-culture with antibodies against human NOS2 showed that immunoreactive protein was expressed in AM, but not in AEC-II as identified by cell shape and size (fig. 5c and 5f). It is worth noting that NOS2 immunoreactivity was decreased in cytokinestimulated AM in comparison with noncultured cells.
These observations may explain the absence of differences in $\mathrm{NO}_{\mathrm{x}}$ generation, because total amount of NOS proteins and their enzymatic activities are too low for generating NO quantities detected by such an indirect method as the Griess reaction.

The authors have shown that neither NOS2 mRNA nor protein could be detected in human AEC-II in vivo, ex vivo or upon cytokine-stimulating conditions in vitro. However, the cell line A549, which was used as the control, expressed NOS2 mRNA and protein upon IFN- $\gamma$ - or TNF- $\alpha$-stimulation. These data corroborate well the results of RoBBins et al. [29]. In contrast to the current study, others have demonstrated a stimulatory influence of LPS and proinflammatory cytokines, including IFN- $\gamma$ on NO production and NOS2 expression by rat AEC-II $[30,31]$. The reason why the stimuli mentioned earlier appeared to induce AM and AEC-II in a rat model, but did not in humans is not clear. There is some evidence that species differences may significantly affect the outcome of experiments for NOS2 induction in AM and AEC-II [32, 33]. It may also be possible that the stimuli and culture conditions, which were used here, are inadequate to stimulate human AM and AEC-II to express NOS2 mRNA and, therefore, do not simulate the complex dynamic processes occurring in vivo, especially during a lung inflammation. In this respect SALEH et al. [9] have demonstrated a weak expression of nitrotyrosine and NOS2 in the airway epithelium and AM of normal lung tissues, which were obtained from the normal part of human lungs by pneumectomy due to lung cancer. Furthermore, it has been shown that in lung cancer patients the production of NO from AM was increased as a result of the in vivo upregulation of NOS2 activity, and not associated with tumour localization in the lungs [4]. The in vitro and in situ hybridization data in this study corroborate well with both observations cited earlier. Thus, all these findings suggest that the NOS2 mRNA accumulation and protein production in AM-AEC-II co-culture is attributable to AM, and both the AM-AEC-II ratio and the presence of IFN- $\gamma$ are critical factors for the NOS2 mRNA induction in human AM under experimental conditions tested.

From the present study, it is not yet clear how AEC-II mediate the upregulation of NOS2 expression by AM. Possible mechanisms include the production of mediator(s) or direct cell-to-cell interactions with involvement of a critical surface expression pattern of known adhesion molecules, or altering the sensitivity of the AM to external cytokine stimulation including IFN- $\gamma$ and IL-1 $\beta$. These questions are currently under investigation.

To conclude, nitric oxide synthase- 2 is the enzyme responsible for the generation of large amounts of nitric oxide, which contribute to inflammatory responses elicited by endotoxin, cytokines or physicochemical stress. In vitro, human alveolar macrophages have repeatedly been shown to be hyporesponsive in nitric oxide synthase-2 expression and nitric oxide production in response to inflammatory stimuli as compared with monocytes/macrophages isolated from peripheral blood [7, 28]. It is likely that, nitric oxide 
synthase- 2 expression and nitric oxide generation in the alveolar compartment of the human lung are under a tight control to protect the host from nitrous oxide or peroxynitrite radicals, which might cause progressive destruction and/or fibrotic remodelling of lung tissue. The authors propose that alveolar epithelial cells type-II play an important role in this control.

Acknowledgements. The authors would like
. Thechto thank $\mathrm{N}$. Hus
nical assistance.

\section{References}

1. Wang $\mathrm{CH}$, Liu CY, Lin $\mathrm{HC}$, Yu CT, Chung KF, Kuo HP. Increased exhaled nitric oxide in active pulmonary tuberculosis due to inducible NO synthase upregulation in alveolar macrophages. Eur Respir $J$ 1998; 11: 809-815.

2. Moodley YP, Chetty R, Lalloo UG. Nitric oxide levels in exhaled air and inducible nitric oxide synthase immunolocalization in pulmonary sarcoidosis. Eur Respir J 1999; 14: 822-827.

3. Paredi P, Kharitonov SA, Loukides S, Pantelidis P, $\mathrm{du}$ Bois RM, Barnes PJ. Exhaled nitric oxide is increased in active fibrosing alveolitis. Chest 1999; 115: $1352-1356$.

4. Liu CY, Wang $\mathrm{CH}$, Chen $\mathrm{TC}$, Lin $\mathrm{HC}, \mathrm{Yu} \mathrm{CT}$, Kuo HP. Increased level of exhaled nitric oxide and up-regulation of inducible nitric oxide synthase in patients with primary lung cancer. Br J Cancer 1998; 78: 534-541.

5. Kobayashi A, Hashimoto S, Kooguchi KY, et al. Expression of inducible nitric oxide synthase and inflammatory cytokines in alveolar macrophages of ARDS following sepsis. Chest 1998; 113: 1632-1639.

6. Albina JE. On the expression of nitric oxide synthase by human macrophages. Why no NO? J Leukoc Biol 1995; 58: 643-649.

7. Aston C, Rom WN, Talbot AT, Reibman J. Early inhibition of mycobacterial growth by human alveolar macrophages is not due to nitric oxide. Am J Respir Crit Care Med 1998; 157: 1943-1950.

8. Nicholson S, Bonecini-Almeida Md G, Lapa e Silva $\mathrm{JR}$, et al. Inducible nitric oxide synthase in pulmonary alveolar macrophages from patients with tuberculosis. J Exp Med 1996; 183: 2293-2302.

9. Saleh D, Barnes PJ, Giaid A. Increased production of the potent oxidant peroxynitrite in the lungs of patients with idiopathic pulmonary fibrosis. Am J Respir Crit Care Med 1997; 155: 1763-1769.

10. Robbins RA, Sisson JH, Springall JH, et al. Human lung mononuclear cells induce nitric oxide synthase in murine airway epithelial cells in vitro: role of TNFalpha and IL-1beta. Am J Respir Crit Care Med 1997; 155: 268-273.

11. Blau H, Riklis S, Van Iwaarden JF, McCormack FX, Kalina M. Nitric oxide production by rat alveolar macrophages can be modulated in vitro by surfactant protein A. Am J Physiol 1997; 272: L1198-L1204.

12. Stamme C, Walsh E, Wright JR. Surfactant protein A differentially regulates IFN-gamma- and LPS-induced nitrite production by rat alveolar macrophages. $A m$ J Respir Cell Mol Biol 2000; 23: 772-779.

13. Somoskovi A, Zissel G, Zipfel PF, et al. Different cytokine patterns correlate with the extension of disease in pulmonary tuberculosis. Eur Cytokine Netw 1999; 10: 135-142.

14. Pechkovsky DV, Zissel G, Ziegenhagen MW, et al. Effect of proinflammatory cytokines on interleukin8 mRNA expression and protein production by isolated human alveolar epithelial cells type II in primary culture. Eur Cytokine Netw 2000; 11: 618-625.

15. Zissel G, Ernst M, Rabe K, et al. Human alveolar epithelial cells type II are capable of regulating T-cell activity. J Investig Med 2000; 48: 66-75.

16. Wright JR, Wager RE, Hawgood S, Dobbs L, Clements JA. Surfactant apoprotein $M_{r}=26,000$ 36,000 enhances uptake of liposomes by type II cells. J Biol Chem 1987; 262: 2888-2894.

17. Reiling N, Ulmer AJ, Hauschildt S. Measurement of eNOS and iNOS mRNA expression using reverse transcription polymerase chain reaction. In: Titheradge MA, ed. Nitric oxide protocols, methods in molecular biology. Totowa. Humana Press Inc., 1997; 155-161.

18. Murray PI, Clay CD, Mappin C, Salmon M. Molecular analysis of resolving immune responses in uveitis. Clin Exp Immunol 1999; 117: 455-461.

19. Goldmann T, Wiedorn KH, Olert J, et al. Analysis of transcriptional gene activity by the use of in situ hybridization and a new fixative (HOPE). Pathol Res Pract 2000; 197: 287.

20. Landmann R, Wesp M, Obrecht JP. Cytokine regulation of the myeloid glycoprotein CD14. Pathobiology 1991; 59: 131-135.

21. Payne JB, Nichols FC, Peluso JF. The effects of interferon-gamma and bacterial lipopolysaccharide on CD14 expression in human monocytes. J Interferon Res 1992; 12: 307-310.

22. Kharitonov SA, Yates D, Robbins RA, LoganSinclair R, Shinebourne EA, Barnes PJ. Increased nitric oxide in exhaled air of asthmatic patients. Lancet 1994; 343: 133-135.

23. van Straaten JF, Postma DS, Coers W, Noordhoek JA, Kauffman HF, Timens W. Macrophages in lung tissue from patients with pulmonary emphysema express both inducible and endothelial nitric oxide synthase. Mod Pathol 1998; 11: 648-655.

24. Guo FH, De Raeve HR, Rice TW, Stuehr DJ, Thunnissen FB, Erzurum SC. Continuous nitric oxide synthesis by inducible nitric oxide synthase in normal human airway epithelium in vivo. Proc Natl Acad Sci USA 1995; 92: 7809-7813.

25. Comhair SA, Thomassen MJ, Erzurum SC. Differential induction of extracellular glutathione peroxidase and nitric oxide synthase 2 in airways of healthy individuals exposed to $100 \% \mathrm{O}(2)$ or cigarette smoke. Am J Respir Cell Mol Biol 2000; 23: 350-354.

26. Geng Y, Lotz M. Increased intracellular $\mathrm{Ca} 2+$ selectively suppresses IL-1-induced NO production by reducing iNOS mRNA stability. J Cell Biol 1995; 129: $1651-1657$.

27. Vodovotz Y, Bogdan C, Paik J, Xie QW, Nathan C. Mechanisms of suppression of macrophage nitric oxide release by transforming growth factor beta. $J$ Exp Med 1993; 178: 605-613.

28. Reiling N, Ulmer AJ, Duchrow M, Ernst M, Flad HD, Hauschildt S. Nitric oxide synthase: mRNA 
expression of different isoforms in human monocytes/ macrophages. Eur J Immunol 1994; 24: 1941-1944.

29. Robbins RA, Barnes PJ, Springall DR, et al. Expression of inducible nitric oxide in human lung epithelial cells. Biochem Biophys Res Commun 1994; 203: 209-218.

30. Punjabi CJ, Laskin JD, Pendino KJ, Goller NL, Durham SK, Laskin DL. Production of nitric oxide by rat type II pneumocytes: increased expression of inducible nitric oxide synthase following inhalation of a pulmonary irritant. Am J Respir Cell Mol Biol 1994; 11: 165-172.

31. Warner RL, Paine RR, Christensen PJ, et al. Lung sources and cytokine requirements for in vivo expression of inducible nitric oxide synthase. Am J Respir Cell Mol Biol 1995; 12: 649-661.

32. Kobzik L, Bredt DS, Lowenstein CJ, et al. Nitric oxide synthase in human and rat lung: immunocytochemical and histochemical localization. Am J Respir Cell Mol Biol 1993; 9: 371-377.

33. Jesch NK, Dorger M, Enders G, et al. Expression of inducible nitric oxide synthase and formation of nitric oxide by alveolar macrophages: an interspecies comparison. Environ Health Perspect 1997; 105: Suppl. 5, $1297-1300$. 